\title{
ORGANIZATIONAL JUSTICE PERCEPTION AND JOB BURNOUT AMONG NURSES AT PORT SAID SELECTED HOSPITALS
}

\author{
Shereen Salah Eldossoqi Eldossoqi', Safaa Abd El Moniem Zahran'2, \\ Takwa Rashwan Mohamed Abd-El hady ${ }^{3}$
}

Head Nurse at ElMansoura Chest Hospital, Dakahlia Governorate ${ }^{1}$, Assist. Prof. of Nursing Administration, Faculty of Nursing, Tanta University ${ }^{2}$, Lecturer of nursing administration, Faculty of Nursing, Port Said University, Egypt ${ }^{3}$

\begin{abstract}
Background: Organization justice alludes to the degree to which nurses perceive working environment strategy, cooperation, and results to be reasonable, a major result of low levels of justice in organizations is increasing levels of job burnout among nurses. Study aim: is to investigate organizational justice perception and their relation to job burnout among nurses at Port Said selected Hospitals. Subjects and Method: Descriptive correlational examination configuration was led in all inpatient divisions at Port-Said selected Hospitals on 206 nurses. Data collection tools incorporated Colquitt's Organizational Justice Scale and Maslach Burnout Inventory and content validated by a panel of specialists. Results: The study results revealed that around half of nurses had a moderate degree of overall organizational justice and more than one third of nurses had moderate levels of emotional exhaustion. Additionally, less than three quarters of nurses had low levels of depersonalization. Likewise, overall organizational justice and it's all dimensions has a statistical significant negative correlation with total job burnout. Conclusion and recommendations: Nurses' perceived moderate degree of organizational justice, interactional justice scored the highest percentage. Whereas, a moderate level of burnout. Negative significant correlation between organizational justice and job burnout. However, negative significant correlations between all organizational justice and its dimensions with emotional exhaustion, depersonalization and total job burnout. The study recommends that a performance appraisal system with relevant job description should be applied to distributive justice by nurse manager.
\end{abstract}

Keywords: Job burnout, Nurses, Organizational justice. 


\section{INTRODUCTION}

Nurses as a crucial part of the work power in the medical care framework (Chiou, Chiang, Huang, Wu, \& Chien, 2013). Nurses as the forefront labor force of health care system have greatly affected the patients' perspectives and the level of care provided (Lu, Barriball, Zhang, \& While, 2012). The manner in which administrators act and treat staff would influence their perspectives and working practices (Jafari, \&Bidarian, 2012). At the point when individuals have an inspirational mentality to their work, their supervisor, division or association they work in, they become more roused proficiently to work (Bidarian, \& Jafari, 2012).

Justice is identified as an achievement or judgment that is deemed right moral on the base of ethics, faith, equity, law or fairness (Pekurinen et al., 2017). Recently, view of nurses of how health care institution handle them equally or unequally is known as organizational justice (Al-zu bi, 2010; Lambert, Hogan, \& Cheeseman, 2013) Organizational justice was identified as nurses perception about institutional fairness ( Brockner , 2011), that may take the form of approach work openings, equivalent advancement possibilities, reasonable compensation system, and arrangement of satisfactory data in regards to the association and its choices (Cole , Bernerth , \&Walter ,2010). One of the focal resources for authoritative achievement and the main supporter to nurses to accomplishing position fulfillment (Fatt, Khin, \& Heng, 2010). Likewise, organizational justice is one of the imperative variables in improvement of the association and its representatives in helping and supporting those (Lotfi \& Pour, 2013).

In view of individuals' perceptions of fairness inside their association, three dimensions of organizational justice have been characterized including the distributive, procedural, and interactional justice (Williamson \& Williams, 2011). First dimension, distributive justice is identified with trustworthiness and precision in the assignment of authoritative assets. The perception of distributive justice is the conviction that nurses ought to obtain an affirmation of their commitment to the foundation's pay and that it meets the degree of their involvement according to their perception (Özsoy \& Ekici, 2017).

Secondly, procedural justice concerns the variety of process, techniques or regulations utilized to find out the physical facilities, benefits, working environment 
and execution assessment of nurses (Heponiemi et al., 2011). All in all, it may be characterized as the decency of the process by which results are resolved (Lind \&Tyler, 1988), identifying to impacts such as consistency, predisposition concealment, representativeness, precision, correctness, and ethical processes (Heponiemi et al., 2011).

Third dimension, interactional justice which has two sub-dimensions, interpersonal and informational justice (Gür, 2014). Interpersonal justice is related to nurses being consulted by the administrator on how choices are taken, and how junior and senior staff respects each other (Özsoy \& Ekici, 2017). Informational justice is commonly utilized, from educating young people about institutional procedures, to social and different issues relating to nurses. Furthermore, the security of advantages regarding the justice of staff's data giving (Gür, 2014). According to Yang and Jung (2009) who suggest that organizations can reduce the occurrence of nurses' job burnout by reducing unfair practices and those individuals differ in their response to injustice.

Guan et al. (2017) described job burnout as an occupational risk that imparts psychosomatic effects on nurses, thus precludes effectiveness and wastes human resources. Also, Carolina (2010) defined job burnout as a condition of substantial and expressive fatigue attributable to inappropriate working conditions. In addition Lambert, Hogan, Barton-Bellessa and Jiang (2012) defined it as the discontent, anxiety and psychological pain that result from dullness at work and lead to a person's emotional and physical exhaustion.

Job burnout depicts a syndrome characterized by emotional exhaustion, cynicism or depersonalization, and reduced or lack of personal accomplishment, arising from long haul introduction to genuinely testing stressors (Leka, Jain, \& world health organization, 2010). Emotional exhaustion is a continuous feeling of emotional depletion in the workplace and this dimension is considered one of the most important dimensions of job burnout, as it represents the main stone in the structure of job burnout (de França, Ferrari, Ferrari, \& Alves, 2012).

Depersonalization refers to the concept of human characteristics, which contain the continuous sense of lacking idealism, where the individual alternative to rough dealing with colleagues, which extremely affects the form of dealing with each 
other, in spite of the different views of researchers about the name, they agreed that it represented pessimism, harshness in dealing with others, coldness, and frequent criticism (Maruyama, Suzuki, \& Takayama, 2016). Depersonalization is improvement of pessimistic, insensitive and critical perspectives to the beneficiaries of one's administrations (Schaufeli \& Salanova, 2014).

Lack of personal accomplishment alludes to the advancement of negative mentalities and sensations of inadequacy with respect to one's experience (Moliner, Martínez-Tur, Peiró, Ramos, \& Cropanzano, 2005). Motivation decline and decreased personal accomplishment also cause the person is unable to find his competence feeling in doing personal duties (Safari, Tamizifar, \& Jannati, 2012). It additionally characterized as the sensations of inadequacy and an absence of profitability, a failure to adapt to ordinary circumstances, and diminished accomplishment in work. Inefficacy is the more mind boggling measurement of job burnout (Callahan, Christman, \& Maltby, 2018).

Job burnout lead to reduced work performance, higher absenteeism, decreased transparency and efficiency, more conflicts, role transition, interpersonal conflicts with colleagues, increased health costs, individual turnover, mental and physical changes, material misuse, and diminished services quality provided to patients after that dissatisfaction with medical services, all of which negatively affect patients and clients. Therefore, detection and avoidance of job burnout is also of utmost importance while, it is about improving individual mental health and improving the quality of care (Maslach \& Leiter 2016).

\section{Significance of study:}

Justice is a critical point for understanding authoritative conduct. De Cremer, Van Knippenberg, Van Knippenberg, Mullenders and Stinglhamber (2005) portrayed organizational justice as a ruling subject in authoritative life. The significance of examining organizational justice in the work environment has been underscored by decision that caused a feeling of working for justice or absence of fairness in the working environment, which can cause increment in degrees of job burnout. Today, organizational justice is considered as one of the most famous themes in organizational behavior research (Fortin, 2008).

The examination gave a rich record of the pith of living inside organizational justice from nurses' perspective. McDermott et al. (2013) found that procedural and interactional justice indirectly affects weariness through distributive injustice. 
Moreover, it was discovered that distributive injustice is indirectly related to shortterm absences through exhaustion. Job burnout is a significant indicator of boss dysfunctions in the health care work environment (Gholampour \& Pourshafei, 2018). Along these lines, in the current examination will be led to analyze the connection between nurses' perception of organizational justice and job burnout at Port Said selected Hospitals.

\section{AIM OF STUDY:-}

This study aimed to investigate organizational justice perception and their relation to job burnout among nurses at Port Said Hospitals through:

1. Assess nurses' perception about organizational justice at Port Said selected Hospitals.

2. Determine the level of job burnout among nurses at Port Said selected Hospitals.

3. Find out organizational justice perception and its relation to job burnout.

\section{SUBJECTS AND METHODS}

\section{(I) TECHNICAL DESIGN:}

\section{Research design: -}

Descriptive correlational research design.

\section{Setting:}

The present study was conducted in all inpatient units at Port Said selected Hospitals namely: As-Salam Port Said Hospital, Al hayat Port fouad Hospital and El-Zohour Hospital.

\section{Subjects}

The study subject were included all nurses who working in all inpatient units in Port said selected Hospitals during the time of data collection with a total number of (206) nurses. Selected by simple random according to the following inclusion criteria, nurses have at least six months of experience.

\section{Tools for Data Collection:}

Data collection tools included two tools namely: - Organizational justice scale and Maslach Burnout Inventory

Tool I: Organizational Justice Scale: This tool includes two parts: 
First part: nurse's personal and job characteristics. It asked about age, gender, hospital name, department, educational qualification, and total years of experience in nursing.

The second part: Organizational Justice Scale: This part was developed by Colloquitt (2001) to determine organizational justice as perceived by nurses. The statements are categorized into three dimensions as follows distributive justice (4 items), procedural justice ( 7 items) and interactional justice (9 items). Scoring: Each statement was scored 3 for "large extent", 2 for "moderate extent" and 1 for "small extent" according to tool instructions. The scores of statements of each dimension and for the total scale were summed-up and converted into percent scores. They were then categorized into "greater than or equal to $75 \%$ indicates large extent perception, while a score of less than 50\% indicates small extent organizational justice perception among nurses.

Second tool: Maslach Burnout Inventory:

This scale was developed by Maslach Burnout Inventory. It was developed by (Maslach, Jackson, \& Leiter, 1996). MBI: Maslach burnout inventory. Sunnyvale, CA: CPP, Incorporated. the questionnaire has 22 statements categorized into three dimensions safety domains as follows: emotional exhaustion (9 items), depersonalization (5 items) and personal accomplishment (8items). Scoring: The responses from "never" to "few times a week and every day" were scored from 1 to 4 respectively. A score of $75 \%$ or higher was considered as high job burnout perception among nurses, while a lower score was considered low job burnout perception among nurses.

\section{Operational Design:}

The operational design covers the preparatory phase including content validity, reliability, pilot study, fieldwork.

\section{Preparatory phase:}

Review of literature related to the problem and aims to acquire theoretical knowledge of related administrative principles, using current national and international related literature, articles, periodicals, magazines and internet of the various aspects concerning organizational justice and nurses' burnout. Also this phase was concerned 
with translation, validation and preparation of tool for data collection with managerial arrangement to accomplish the implementation phase.

\section{Validity:}

The tool was translated to Arabic language by researcher and then retranslated to English again. The content validity was examined by a panel of five experts' opinions in relevant filed to assure that the content was assessing what the researcher want to measure.

\section{Reliability:}

The tools of the study were tested by using Cronbach's alpha coefficient test to assess the consistency of the research tool.

Reliability was measured for tool I using Cronbach's alpha coefficient test (0.865) which indicate that this tool is $86.8 \%$ reliable.

Reliability was measured for tool II using Cronbach's alpha coefficient test (0.947) which indicate that this tool is $94.7 \%$ reliable.

\section{Pilot study:}

A pilot study was carried out after the development of the study tools, and before the data collection phase. A pilot study was carried out on 21 nurses who represent $10 \%$ of the nurses who fulfilled criteria of the study to test applicability, feasibility, and objectivity and to estimate the needed time to fill the date collection sheets, and then necessary modification was done according to the result of the pilot study. Nurses responded well to the questionnaire during the pilot study and changes required to the questionnaire, and this pilot study was excluded from the original sample. As a result, data obtained from the pilot study were analyzed and accordingly necessary modifications were done. Completion of nurses' sheet took 15-20 minutes

\section{Field work:}

This study was carried out in the period started from October 2018 to end of January 2019. The researcher met the respondents during the different shifts to distribute the questionnaire. Data were collected from nurses within Port Said selected Hospitals. The questionnaire sheet were filled in by the study subjects after explain the aim and purpose of the study. They were assured that the information given would be utilized confidentially and used for the research purpose only, and the researcher explained to them how to fill in the sheets. The respondents filled the questionnaire sheet individually by themselves fill the sheet. The researcher remained with the nurses until questionnaires were completed to ensure objectivity of the responses and to check that 
all items were answered. Data were collected by the researcher from nurses at three days per week in different shifts. Data were collected by the researcher over four month's period.

\section{Administrative Design:}

Before conduction of the study, an official letters from the Dean of the Faculty of Nursing and Vice Dean for Post-Graduate Studies and Researches were sent to the selected area of the study. The director of the forementioned setting were contacted and informed in order to obtain permission to include the nurses on the present research.

\section{Ethical Considerations:}

An informed consent was obtained from nurses to participate in the study after explaining the purpose and the nature of the study.

The studied nurses were informed that their participation is voluntary and they have the right of withdrawing from the study at any time and ensuring the confidentiality of the information collected and will be used for scientific research only and anonymity is guaranteed.

\section{Statistical Design:}

Data analysis was performed using IBM SPSS statistical software version 22. The data were explored. Descriptive statistics with mean, median and standard deviation (SD) for continuous variables and frequency for categorical variables were analyzed. Qualitative variables were compared using qui square test $\left(\boldsymbol{X}^{2}\right)$ as the test of significance and independent, ( $r$ ) test was used to identify the relationship between two variables. The $\mathrm{p}$ value is the degree of significance. A significant level value was considered when the $p$ value $\leq 0.05$ and a highly significant level value was considered when the $p$-value $\leq 0.001$, while the $\mathrm{p}$-value $>0.05$ indicates non-significance results.

\section{RESULTS:}

Table (1): Show personal characteristics of nurses in the study setting. The study sample consisted of 206 nurses. The results reveal that, around half $(51.5 \%)$ of nurses were in As- Salam Port Said hospital. As well, more than one third (39.3\%) of them aged between thirty to less than forty years old followed by more than one third (38.8\%) of them aged between twenty to less than thirty years old. The mean score of nurses' age is $33.4 \pm 7.8$. The results revealed that, the vast majority of nurses $(92.2 \%)$ were females. Regarding educational qualification, more than one third (38.3\%) of 
nurses having nursing Diploma . In relation to years of experience more than one third $(41.7 \%)$ of them had from one to less than ten years of experience. While the minority (4.4\%) of them had from thirty to less than forty years of experience. The mean score

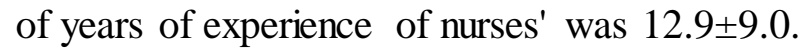

Table (2): Illustrate levels of organizational justice among nurses. It demonstrates that $43.2 \%$ of nurses had a moderate level of organizational justice. In light of this table, more than one third (35\%) of nurses had low perception about interactional justice. Also, it was found that mean of interactional justice is the highest score of organizational justice dimensions $(30.2 \pm 8.0)$. While less than half $(47.6 \%)$ of them perceived that there was a low level of procedural justice. As shown in this table, more than two third (68\%) of them perceived that level of distributional justice was low. Also, it was found that mean of distributional justice is the lowest score of organizational justice dimensions (10.3 \pm 3.6$)$.

Table (3): Illustrate levels of job burnout among nurses. Thus, it showed that $68.9 \%$ of nurses had moderate level of job burnout. On the other hand, it was found that $46.1 \%$ of nurses perceived had moderate level of personal accomplishment. While $41.7 \%$ of them perceived that there was a moderate level of emotional exhaustion. Whereas $74.3 \%$ of them perceived that level of depersonalization was low

Table (4): Reveals the relation between levels of organizational justice and job burnout among nurses. As indicated in the table, there was high significant relation between nurses perception about organizational justice and their job burnout at $p$ value <0.01. It was evidenced that there was $70 \%$ of nurses had high perception of organizational justice and low level of job burnout. While, there was $87.4 \%$ of them had low perception of organizational justice and moderate level of job burnout.

Table (5): Illustrate the relation between levels of nurses' perception about organizational justice and their socio-demographic characteristics. The table shows that there was significant relation between levels of nurses perception about organizational justice and their age, educational level and years of nursing experience at $\mathrm{p}$ value $>0.05$. As shown in the table, 55\% nurses who are in the age group from twenty to less than thirty had low perception of organizational justice. It was found that $53.5 \%$ of nurses who are experienced one to less than 10 years had low perception 
of organizational justice. The results also revealed $25.3 \%$ of nurses with nursing Diploma had high perception of organizational justice.

Table (6): Illustrate the relation between nurses' levels of job burnout and their socio-demographic characteristics. Revealed that there was high significant relation between age, educational level and level of job burnout at $\mathrm{p}$ value $<0.01$. While, there was slight significant relation between duration of nursing experience and level of job burnout at $\mathrm{p}$ value $<0.05$. It can be noticed that $66.7 \%$ of nurses who are in the age group from twenty to less than thirty had high perception about job burnout. Whereas, $66.7 \%$ of nurses who are experienced one to less than 10 years had high perception about job burnout. Also, it was found that $88.9 \%$ of nurses who were graduated from nursing faculty had the highest level about job burnout.

Table (7): Illustrates correlation between organizational justice and maslach burnout among nurses. In light of this table, that there 'were high statistically significant negative correlations between total organizational justice, procedural justice and interactional justice and emotional exhaustion where $\mathrm{p} \leq 0.05$ where $(\mathrm{r}=-$ $0.497, r=-0.364, r=-0.408$, respectively). It's obvious that there were a high statistically significant negative correlations between total organizational justice, procedural justice and total job burnout where $\mathrm{p} \leq 0.05$ where ( $\mathrm{r}=-0.511, \mathrm{r}=-0.385$, respectively). It was evidenced that there were high statistically significant positive correlations between total organizational justice, distributional justice and interactional justice and personal accomplishment ( $\mathrm{r}=-0.401, \mathrm{r}=-0.311, \mathrm{r}=-0.347$, respectively). 
Table (1): Socio-demographic characteristics of nurses $(n=206)$

\begin{tabular}{|c|c|c|}
\hline \multirow{2}{*}{ Socio-demographic characteristics } & \multicolumn{2}{|c|}{ Nurses } \\
\hline & No. & $\%$ \\
\hline \multicolumn{3}{|l|}{ Hospital of employment } \\
\hline As-Salam port said $\mathrm{H}$. & 106 & 51.5 \\
\hline Alzohour H. & 52 & 25.2 \\
\hline Alhayat port fouad $\mathrm{H}$ & 48 & 23.3 \\
\hline \multicolumn{3}{|l|}{ Age (years) } \\
\hline $20-<30$ & 80 & 38.8 \\
\hline $30-<40$ & 81 & 39.3 \\
\hline $40-<50$ & 42 & 20.4 \\
\hline $50-<60$ & 3 & 1.5 \\
\hline Min-Max, & \multirow{2}{*}{\multicolumn{2}{|c|}{$\begin{array}{l}21.0-58.0 \\
33.4 \pm 7.8\end{array}$}} \\
\hline Mean \pm SD & & \\
\hline \multicolumn{3}{|l|}{ Gender } \\
\hline Male & 16 & 7.8 \\
\hline Female & 190 & 92.2 \\
\hline \multicolumn{3}{|l|}{ Educational level } \\
\hline Nursing faculty & 57 & 27.7 \\
\hline Technical nursing institute & 70 & 34.0 \\
\hline Nursing diploma & 79 & 38.3 \\
\hline \multicolumn{3}{|l|}{ Duration of nursing experience (years) } \\
\hline $1-<10$ & 86 & 41.7 \\
\hline $10-<20$ & 63 & 30.6 \\
\hline $20-<30$ & 48 & 23.3 \\
\hline $30-<40$ & 9 & 4.4 \\
\hline Min-Max & \multicolumn{2}{|c|}{$1.0-36.0$} \\
\hline Mean + SD & \multicolumn{2}{|c|}{$12.9 \pm 9.0$} \\
\hline
\end{tabular}

Table (2): Levels of organizational justice among nurses $(n=206)$

\begin{tabular}{|l|l|l|l|l|l|l|l|}
\hline \multirow{2}{*}{ Organizational justice } & \multicolumn{6}{|l|}{ Organizational justice levels } & \multirow{2}{*}{} \\
\cline { 2 - 8 } & High & \multicolumn{2}{l|}{ Moderate } & \multicolumn{2}{l|}{ Low } \\
\cline { 2 - 8 } & No. & $\%$ & No. & $\%$ & No. & $\%$ & Mean \pm SD \\
\hline Distributional justice & 24 & 11.7 & 42 & 20.3 & 140 & 68.0 & $10.3 \pm 3.6$ \\
& & & & & & & \\
\hline Procedural justice & 40 & 19.4 & 68 & 33.0 & 98 & 47.6 & $21.0 \pm 6.2$ \\
\hline Interactional justice & 65 & 31.6 & 69 & 33.4 & 72 & 35.0 & $30.2 \pm 8.0$ \\
\hline Total score & 30 & 14.6 & 89 & 43.2 & 87 & 42.2 & $61.5 \pm 15.3$ \\
\hline
\end{tabular}


Table (3): Levels of job burnout among the nurses $(n=206)$

\begin{tabular}{|c|c|c|c|c|c|c|}
\hline \multirow{3}{*}{ Maslach Burnout } & \multicolumn{6}{|c|}{ Nurses burnout levels } \\
\hline & \multicolumn{2}{|r|}{ High } & \multicolumn{2}{|c|}{ Moderate } & \multicolumn{2}{|r|}{ Low } \\
\hline & No. & $\%$ & No. & $\%$ & No. & $\%$ \\
\hline Emotional exhaustion & 42 & 20.4 & 86 & 41.7 & 78 & 37.9 \\
\hline Depersonalization & 5 & 2.4 & 48 & 23.3 & 153 & 74.3 \\
\hline Personal accomplishment & 87 & 42.2 & 95 & 46.1 & 24 & 11.7 \\
\hline Total score & 9 & 4.4 & 142 & 68.9 & 55 & 26.7 \\
\hline
\end{tabular}

Table (4): Relation between level of Organizational justice and Maslach Burnout among nurses $(n=206)$

\begin{tabular}{|c|c|c|c|c|c|c|c|}
\hline \multirow{3}{*}{$\begin{array}{l}\text { Maslach } \\
\text { Burnout }\end{array}$} & \multicolumn{6}{|c|}{ Organizational justice } & \multirow{3}{*}{$\mathbf{X}^{2}$} \\
\hline & \multicolumn{2}{|c|}{$\begin{array}{l}\text { Large extent } \\
\qquad(\mathrm{n}=\mathbf{3 0})\end{array}$} & \multicolumn{2}{|c|}{$\begin{array}{c}\text { Moderate } \\
\text { extent }(n=89)\end{array}$} & \multicolumn{2}{|c|}{$\begin{array}{r}\text { Small extent } \\
(\mathbf{n}=87)\end{array}$} & \\
\hline & No. & $\%$ & No. & $\%$ & No. & $\%$ & \\
\hline Low & 21 & 70 & 29 & 32.6 & 5 & 5.7 & \\
\hline Moderate & 9 & 30 & 57 & 64 & 76 & 87.4 & $P$ value \\
\hline High & 0 & 0 & 3 & 3.4 & 6 & 6.9 & \\
\hline
\end{tabular}


Table (5): Relation between levels of nurses perception of nurses perception about organizational justice and socio-demographic characteristics $(\mathrm{n}=206)$

\begin{tabular}{|c|c|c|c|c|c|c|c|}
\hline \multirow{3}{*}{$\begin{array}{l}\text { Socio-demographic } \\
\text { characteristics }\end{array}$} & \multicolumn{6}{|c|}{ Organizational justice } & \multirow{3}{*}{ Significance } \\
\hline & \multicolumn{2}{|c|}{$\begin{array}{r}\text { Large extent } \\
(n=30)\end{array}$} & \multicolumn{2}{|c|}{$\begin{array}{c}\text { Moderate } \\
\text { extent } \\
(n=89)\end{array}$} & \multicolumn{2}{|c|}{$\begin{array}{r}\text { Small extent } \\
(n=87)\end{array}$} & \\
\hline & No. & $\%^{\wedge}$ & No. & $\%^{\wedge}$ & No. & $\%^{\wedge}$ & \\
\hline \multicolumn{8}{|l|}{ Hospital of employment } \\
\hline As- Salam port said $\mathrm{H}$. & 14 & 13.2 & 42 & 39.6 & 50 & 47.2 & $X^{2}=4.498$ \\
\hline Alzohour H. & 11 & 21.2 & 23 & 44.2 & 18 & 34.6 & $\mathrm{P}=0.343$ \\
\hline Al hayat port fouad $\mathrm{H}$ & 5 & 10.4 & 24 & 50.0 & 19 & 39.6 & \\
\hline \multicolumn{8}{|l|}{ Age (years) } \\
\hline $20-<30$ & 8 & 10.0 & 28 & 35.0 & 44 & 55.0 & $X^{2}=16.837$ \\
\hline $30-<40$ & 9 & 11.1 & 40 & 49.4 & 32 & 39.5 & $\mathrm{P}=0.002 *$ \\
\hline $40-<$ & 13 & 28.9 & 21 & 46.7 & 11 & 24.4 & \\
\hline \multicolumn{8}{|l|}{ Gender } \\
\hline Male & 2 & 12.5 & 7 & 43.8 & 7 & 43.8 & $X^{2}=0.061$ \\
\hline Female & 28 & 14.7 & 82 & 43.2 & 80 & 42.1 & ${ }^{\mathrm{MC}} \mathrm{P}=1.0$ \\
\hline \multicolumn{8}{|l|}{ Educational level } \\
\hline Nursing faculty & 4 & 7.0 & 29 & 50.9 & 24 & 42.1 & $X^{2}=19.299$ \\
\hline Technical nursing institute & 6 & 8.6 & 24 & 34.3 & 40 & 57.1 & $\mathrm{P}=0.001 *$ \\
\hline Nursing diploma & 20 & 25.3 & 36 & 45.6 & 23 & 29.1 & \\
\hline \multicolumn{8}{|l|}{$\begin{array}{l}\text { Duration of nursing } \\
\text { experience (years) }\end{array}$} \\
\hline $1-<10$ & 10 & 11.6 & 30 & 34.9 & 46 & 53.5 & $X^{2}=16.980$ \\
\hline $10-<20$ & 5 & 7.9 & 31 & 49.2 & 27 & 42.9 & $\mathrm{P}=0.002 *$ \\
\hline $20-<30$ & 15 & 26.3 & 28 & 49.1 & 14 & 24.6 & \\
\hline
\end{tabular}

${ }^{\wedge}$ Percentage is calculated from the total of the row 
Table (6): Relation between levels of nurses job burnout and their socio-demographic characteristics of nurses $(n=206)$

\begin{tabular}{|c|c|c|c|c|c|c|c|}
\hline \multirow{3}{*}{$\begin{array}{l}\text { Socio-demographic } \\
\text { characteristics }\end{array}$} & \multicolumn{7}{|c|}{ Job burnout levels } \\
\hline & \multicolumn{2}{|c|}{$\begin{array}{l}\text { High } \\
(\mathrm{n}=9)\end{array}$} & \multicolumn{2}{|c|}{$\begin{array}{c}\text { Moderate } \\
(\mathrm{n}=142)\end{array}$} & \multicolumn{2}{|r|}{$\begin{array}{l}\text { Low } \\
(n=55)\end{array}$} & \multirow[t]{2}{*}{ Significance } \\
\hline & No. & $\%$ & No. & $\%$ & No. & $\%$ & \\
\hline \multicolumn{8}{|l|}{ Hospital of employment } \\
\hline As- Salam port said $\mathrm{H}$. & 4 & 44.5 & 74 & 52.1 & 28 & 50.9 & 1.264 \\
\hline Alzohour H. & 3 & 33.3 & 37 & 26.1 & 12 & 21.8 & $P$ value \\
\hline $\mathrm{Al}$ hayat port fouad $\mathrm{H}$ & 2 & 22.2 & 31 & 21.8 & 15 & 27.3 & .068 \\
\hline \multicolumn{8}{|l|}{ Age (years) } \\
\hline $20-<30$ & 6 & 66.7 & 61 & 42.9 & 13 & 23.6 & 4.064 \\
\hline $30-<40$ & 3 & 33.3 & 62 & 43.7 & 16 & 29.1 & $P$ value \\
\hline $40-<$ & 0 & 0 & 19 & 13.4 & 26 & 47.3 & $.008 * *$ \\
\hline \multicolumn{8}{|l|}{ Gender } \\
\hline Male & 2 & 22.2 & 11 & 7.7 & 3 & 5.5 & 1.055 \\
\hline Female & 7 & 77.8 & 131 & 92.3 & 52 & 94.5 & $\begin{array}{l}\mathrm{P} \text { value } \\
.074\end{array}$ \\
\hline \multicolumn{8}{|l|}{ Educational level } \\
\hline Nursing faculty & 8 & 88.9 & 42 & 29.6 & 7 & 12.7 & 7.931 \\
\hline Technical nursing institute & 1 & 11.1 & 49 & 34.5 & 20 & 36.4 & $P$ value \\
\hline Nursing diploma & 0 & & 51 & 35.9 & 28 & 50.9 & $.006^{* *}$ \\
\hline \multicolumn{8}{|l|}{$\begin{array}{l}\text { Duration of nursing } \\
\text { experience (years) }\end{array}$} \\
\hline $1-<10$ & 6 & 66.7 & 73 & 51.4 & 7 & 12.7 & 3.701 \\
\hline $10-<20$ & 2 & 22.2 & 49 & 34.5 & 12 & 21.8 & $P$ value \\
\hline $20-<30$ & 1 & 11.1 & 20 & 14.1 & 36 & 65.5 & $.011 *$ \\
\hline
\end{tabular}

Table (7): Correlation between Organizational justice and Maslach Burnout among nurses $(\mathrm{n}=206)$

\begin{tabular}{|l|r|r|r|r|r|r|r|r|}
\hline \multirow{2}{*}{$\begin{array}{l}\text { Organizational } \\
\text { justice }\end{array}$} & \multicolumn{9}{|c|}{ Maslach Burnout } \\
\cline { 2 - 9 } & \multicolumn{2}{|c|}{$\begin{array}{c}\text { Emotional } \\
\text { exhaustion }\end{array}$} & \multicolumn{1}{|c|}{$\begin{array}{c}\text { Pepersonalizatio } \\
\text { accomplishmen }\end{array}$} & \multicolumn{2}{|c|}{ Total score } \\
\cline { 2 - 9 } & $\mathbf{R}$ & $\mathbf{P}$ & $\mathbf{R}$ & $\mathbf{P}$ & $\mathbf{R}$ & $\mathbf{P}$ & $\mathbf{R}$ & $\mathbf{P}$ \\
\hline $\begin{array}{l}\text { Distributional } \\
\text { justice }\end{array}$ & -0.211 & $.018^{*}$ & -0.061 & .064 & 0.311 & $.009 * *$ & -207 & $.026^{*}$ \\
\hline Procedural justice & -0.364 & $.009^{* *}$ & -0.101 & .071 & 0.289 & $.010^{*}$ & -385 & $.008^{* *}$ \\
\hline $\begin{array}{l}\text { Interactional } \\
\text { justice }\end{array}$ & -0.408 & $.007 * *$ & -0.217 & $.013 *$ & 0.347 & $.008^{* *}$ & -128 & $.041^{*}$ \\
\hline Total score & -0.497 & $.005^{* *}$ & -0.306 & $.010^{*}$ & 0.401 & $.007 * *$ & -511 & $.004 * *$ \\
\hline
\end{tabular}




\section{DISCUSSION:}

Nurses are the key employees at health care organizations and they are very close relationship with patients, their perception of justice might affect the quality of care; therefore, should be considered critically. Since nurses' perception of injustice would lead them to become unproductive or make decision to leave their job, the direct and final effect of these consequences would get on patients (Hatam,Fardid, \& Kavosi, 2013). Binns (2008) stated that when nurses perceived organizational justice, this will reduce the mental (emotional) problems, work discouragement, and personal failure among nurses. This consequently will reduce nurses' job burnout and so effectiveness, efficiency and commitment of nurses will increase.

Present study was concerned with exploring the relation between organizational justice and job burnout among nurses through assessing organizational justice, measuring the level of job burnout, and finding out the relation between organizational justice and job burnout among nurses at Port- Said General selected Hospitals.

Concerning perception of nurses toward organizational justice, the present study clarified that majority of nurses perceived that they have a moderate/low level of organizational justice. This finding might be due to injustice of nurse manager in performing appraisal and distribution of incentives, rewards and promotions. Results of this study were congruent with Top and Tekingunduz (2018) who studied the effect of organizational justice and trust on job stress in hospital organizations and stated that respondents displayed moderate levels of organizational justice.

Regarding distributive justice, the result of this study showed that more than two third of nurses perceived that level of distributional justice was low. Also, it was found that mean score of distributional justice is the lowest score of organizational justice dimensions. This may be due to nurses outcome doesn't reflect their effort in work, their outcome not appropriate for the work they have completed, their outcome doesn't reflect what they have contributed to their performance. Results of this study were similar with Seyrek and Ekici (2017) who study nurses' perception of organizational justice and its effect on bullying behavior in the research and education hospitals and state that level of distributional justice is low. 
As regarding to procedural justice, the result of this study showed that less than half of nurses perceived that there was a low level of procedural justice. This finding could be interpreted by nurses haven't been able to appeal and influence the outcome arrived by those procedures. The present study was on the same line with the study of Mohamed (2014) who found that nurses perceived procedural justice as low.

Regarding interactional justice, the result of the present study showed that more than one third of nurses had low perception about interactional justice. Also, it was found that mean of interactional justice is the highest score of organizational justice dimensions. This may be due to nursing shortage and work overload, nurse managers do not have the enough time to release the needed information to all nurses or rationale their actions or decisions such as results of the evaluation process. The present study was on the same line with the study of Özer, Uğurluoğlu and Saygili (2017) who found that participants gave the highest mean score to interactional justice. The present study was inconsistent with Yaghoubi,Afshar and Javadi (2012) who found that interactional justice dimension had the lowest score among nurses.

Concerning perception of nurses toward job burnout, the present study revealed that more than two third of nurses had moderate level of job burnout. This may be due to acuity level of patient care, high level of complexity, increased work load, feelings of being over extended and exhausted by their work, lack of fairness, lack of adequate staff and poor leadership. The finding of the present study was congruent with the study done by Karkar, Dammang and Bouhaha (2015) who study relation between stress and burnout among hemodialysis nurses and Rosales, Labrague and Rosales (2013) they found that nurses reported moderate level of job burnout.

Related to emotional exhaustion, the result of this study showed that more than one third of nurses experienced a moderate level of emotional exhaustion. This may be due to nurse feel used up at the end of the day, feel fatigued when they getting up and have to face another day on their job. Results of this study were congruent with Rosales, Labrague and Rosales (2013) they found that sample of nurses reported moderate level of emotional exhaustion.

Regarding depersonalization, the result of this study showed that less than three quarters of nurses experienced a low level of depersonalization. This might be due to various reasons; nurses become more callous towards people since they took this job, they worry about hardening their job emotionally, they don't really care what 
happens to some patients and they feel patients blame them for some of their problems.

Similar findings were reported by Delpasand, Raeissi, Begdeli and Shahabi (2011) they found that nurses had low level of depersonalization. In contrast with the previous finding, Abdo, El-Sallamy, El-Sherbiny and Kabbash (2016) who found that nurses experienced moderate level of depersonalization.

Concerning personal accomplishment, the findings of the present study clarified that more than one third of nurses experienced a moderate level of personal accomplishment. This might be interpreted by, nurses feel very energetic, and they have accomplished many worthwhile things in their job. This result is confirmed by Gingras, De Jonge and Purdy (2010) who found that nurses experienced moderate level of personal accomplishment. In contrast with the previous finding, Abdo et al. (2016) who was found that nurses experienced high level of personal accomplishment.

The present study clarified that there was high significant relation between organizational justice and job burnout. It was evidenced that there was more than two third of nurses had high perception of organizational justice were perceived low level of job burnout. While, there was majority of nurses had low perception of organizational justice were perceived moderate level of burnout. This result may be related to that, when nurses perceived unfair procedures, policies, interaction, and distribution system, they become emotionally exhausted, depersonalized and have lack of personal accomplishment.

The present study was supported by $\mathrm{Li}$ (2014) revealed that there was a significant relation between organizational justice and their job burnout. The present study was incongruent with Shkoler and Tziner (2017) who found that there is a negative relationship between perceptions of nurses' organizational justice and their job burnout.

Regarding relation between nurses, perception of organizational justice and hospital of employment, the present study revealed that there was no a statistically significant relation between organizational justice and hospital of employment. This might be attributed to that the system of distribution, allocation of resources and procedures was convergent. Laschinger, Wong and Grau (2012) emphasized the 
necessity of nurse managers' utilization of authentic leadership to create supportive work environments and reduce workplace bullying and burnout among nurses.

According to the relation between nurses' perception of organizational justice and their age, the present study revealed that there was significant relation between nurses' age and their organizational justice. It can be noticed that more than half of nurses who are in the age group from twenty to less than thirty had low perception of organizational justice. This result may be attributed to that young nurses are oriented with organizational practices, policies, rules and regulation of hospital that lead them to become low perception of organizational justice.

The present study was consistent with Yaghoubi,Afshar and Javadi (2012) who found that there was a significant relationship between nurses organizational justice and their age. Also, the present study was consistent with Al-Zu'bi (2010) who found that there is significant relationship exists between age of respondents and their perceptions of organizational justice.

As regards to relation between nurses' perception of organizational justice and their gender, the present study revealed that there was no significant relation between gender and organizational justice. This may be related to that there wasn't difference of distribution of resources and treatment between male and female nurses. The present study was consistent with Jafari and Bidarian (2012) who found that there is no difference between gender and organizational justice. This finding was incongruent with Jafari and Bidarian (2012) who found that there is no difference between male and female perception of justice.

Regarding to relation between nurses perception of organizational justice and their educational level, the present study revealed that there was significant relation between nurses organizational justice perception and their educational level. Also, it was found that nurses with nursing diploma had a perception of organizational justice higher than Bachelors. This result may be due to that nurses who have Bachelor degree tend to seek better positions and be treated more respectfully, and expect more justice in the organization.

The present study was consistent with Golparvar and Arizi (2008) who mentioned that when people continue their studies they tend to seek better positions 
and be treated more respectfully, and expect more justice in the organization compared to the others with less education.

Regarding relation between nurses' perception of organizational justice and their years of experience, the present study revealed that there was significant relation between nurses' organizational justice perception and their years of nursing experience. Also, it was found that more than half of nurses who are experienced one to less than ten years had low perception of organizational justice. This result may be due to nurses who are less experienced have lack of information about organizational goals and policies, they need more appreciation and rewards for achievement, and they didn't have the opportunity to participate in decision making. This finding was supported by Mohamed, Higazee and Goda (2018) who found that there was a significant relationship between nurses' organizational justice perception and their years of experience.

According to relation between nurses' perception about burnout and hospital of employment, the present study revealed there was relation between hospital of employment and burnout. Nurses who were in As- Salam hospital experienced moderate perception of burnout. These findings might be because of nurses who were in As- Salam hospital experienced high work load, lack of resources and shortage of nurses. On the same line with a study by Karkar, Dammang and Bouhaha (2015) who mentioned that nurses reported moderate level of burnout regarding their work place.

Concerning relation between nurses' perception about job burnout and their age, the present study found that there was high significant relation between nurses' age and their job burnout. The present study revealed that approximately two third of nurses who are in the age group from twenty to less than thirty had high perception about job burnout. This finding could be related to that young nurses have high work-load, poor time schedule such as continuous and consecutive night shift such as one month. Results of this study were on the same line with the study done by Elkonin and Van der Vyver (2011) who confirmed that nurses' age is inversely correlated with their job burnout, with younger nurses being more susceptible to job burnout. 
Concerning relation between nurses' perception of burnout and their gender, there was a significant association between gender and degree of job burnout. Female nurses more than three quarters had high perception of burnout. This may be due to female nurses have more responsibilities more than male nurses. Results of this study were inconsistent with Lahana et al. (2017) they found that there was no significant association between gender and degree of burnout.

Regarding relation between nurses' perception about job burnout and their educational level. The present study revealed that there was high significant relation between educational level and level of job burnout among nurses. It was found that majority of nurses who were graduated from nursing faculty had high level about job burnout. This may be due to nurses who were graduated from nursing faculty have greater responsibilities, they were working in special units and with critical patients that lead to higher level of stress and job burnout. The present results confirmed by Ismail et al. (2015) found that nurses with a high degree had a high level of job burnout.

Regarding relation between nurses' perception about job burnout and duration of nursing experience, there was slight significant relation between duration of nursing experience and level of job burnout. The result clarified that two third of nurses who are experienced one to less than ten years had high perception about job burnout. This may be related to that, low experienced nurses didn't have the ability to manage critically ill patient. Results of this study were supported by Ismail et al. (2015) who found that nurses with experience less than five years had a high level of job burnout.

According to correlation between organizational justice and job burnout dimensions among nurses, it was found that there 'were high statistically significant negative correlations between total organizational justice, procedural justice and interactional justice and emotional exhaustion as a dimension of job burnout. It's obvious that there were high statistically significant negative correlations between total organizational justice, procedural justice and total job burnout. It was evidenced that there were high statistically significant positive correlations between total organizational justice, distributional justice and interactional justice and personal accomplishment and total job burnout. This result may be due to a hospital which is fair in its system regarding distributive, procedural, interactional justice, providing 
motivation to nurses to continue their association with their job. Fairness and justice offers opportunity to the nurses to feel personally accomplished and minimizing feel of emotionally exhausted and depersonalization of nurses.

This finding was supported by Aghaei, Moshiri and Shahrbanian (2012) who found that there was negative a statistically significant relationship between the components of procedural justice and employees job burnout. Also it was congruent with Saeed, Syed and Faria Rabbi (2015) who found that there was negative significant relationship between organizational justice and job burnout of nurses. Also, there is significant and negative relationship between procedural justice and employees total job burnout. Also, a study by Zhang, Li and $\mathrm{Wu}$ (2012) found that organizational justice predicted negatively about emotional exhaustion, but positively predicted about personal accomplishment.

This finding was congruent with Liao, Xu and Tang (2012) who found that there was a significant relation between nurses' perception of organizational justice and personal accomplishment as dimension of job burnout. This finding was supported by Elçi, Karabay and Akyüz (2015) who found that employees working in the financial services perceived that organizational justice, distributive justice and procedural justice significantly have negative effect on emotional exhaustion and depersonalization as dimensions of job burnout.

Similar findings were reported by Al-Zahrani's (2011) showed that nurses perception about distributive, procedural, and interactional justice are negatively associated with job burnout. Also, he found that there is negative correlation of statistical significance between distributive justice and emotional exhaustion and depersonalization of job burnout. Furthermore, this finding was supported by Juan, Omar and Salessi (2018) who proved that nurses' perception of organizational justice perceptions were negatively related to their job burnout.

This finding was inconsistent with Aghaei, Moshiri and Shahrbanian (2012) who found that there is no significant correlation between distributive justice and interactional justice with job burnout. In addition, it was incongruent with Saeed, Syed and Faria Rabbi (2015) who found that there is no significant relationship between distributive justice and interactional justice with job burnout. The foregoing present study finding was disagreed with Lambert et al. (2010) who revealed that 
both distributive and procedural justice had a statistically significant inverse association with employees' job burnout.

According to, Neami and Shokrkon (2004) who clarified that feeling of justice is one of the factors that affecting staff burnout. From a long time ago social and management scientists have realized the importance and necessity of social justice as an essential base for the effectiveness of organizational processes. Nowadays, for hospitals to be successful and to achieve its organizational objectives it is imperative that its nurses are perceived justice this will lead to decreasing level of burnout.

\section{CONCLUSION:}

Based on the study findings, it can be concluded that there was a moderate level of organizational justice among nurses at selected hospitals in Port-Said. In addition, interactional justice scored was the highest justice dimension from the view of nurses' point. Whereas, distributional justice was the least percentage among nurses. Besides, it can be concluded that there was a moderate level of job burnout among nurses. In addition, depersonalization dimension was the lowest level from the view of nurses' point.

Also, there was negative significant correlation between organizational justice and job burnout among nurses. However, statistically significant negative correlations between organizational justice and its dimensions with emotional exhaustion, depersonalization and total job burnout among nurses.

\section{RECOMMENDATIONS:}

1. Nurse Manager applying a fair performance evaluation system to distributive justice with an appropriate job description.

2. Nurse Manager is sure that all procedures practiced consistently across nurses, absolutely free from favoritism and be sure that correct information is collected and utilized at decision making.

3. Encourage nurse managers to use two ways communication to improve interactional justice.

4. Conduct periodic meetings between nurse manager and staff nurses to share and discuss nurses' problems and share nurses in creating solutions for their problems.

5. In services department conducting continuous educational programs for nurses to increase their awareness about organizational justice perception. 
6. Further research is suggested to investigate the effectiveness of implemented supported programs in different hospitals to achieve more generalizable results and reinforce organizational justice allover Egypt Hospitals.

\section{REFERENCES:}

Abdo, S. A., El-Sallamy, R. M., El-Sherbiny, A. A., \& Kabbash, I. A. (2016). Burnout among physicians and nursing staff working in the emergency hospital of Tanta University, Egypt. East Mediterr Health J, 21(12), 906-915.

Aghaei, N., Moshiri, K., \& Shahrbanian, S. (2012). Relationship between organizational justice and job burnout in employees of Sport and Youth Head Office of Tehran. Advances in Applied Science Research, 3(4), 2438-2445.

Al-Zahrani, A. (2011). The impact of organizational justice on job burnout: A study in private hospitals in Riyadh, Saudi Arabia. Interdisciplinary journal of Contemporary Research in business, 3(6), 627-637.

Al-Zu'bi, H. A. (2010). A study of relationship between organizational justice and job satisfaction. International journal of business and management, 5(12), 102.

Binns, A. R. (2008). An examination of the effects of organizational justice on work behavior after negotiation and salary arbitration. A dissertation for the degree of Doctor of Philosophy. Harvard University, Department of Sociology.

Bidarian, S., \& Jafari, P. (2012). The relationship between organizational justice and organizational trust. Procedia-Social and Behavioral Sciences, 47, 1622 1626.

Brockner, J. (2011). A contemporary look at organizational justice: Multiplying insult times injury. Routledge

Callahan, K., Christman, G., \& Maltby, L. (2018). Battling burnout: strategies for promoting physician wellness. Advances in pediatrics, 65(1), 1-17.

Carolina, D. S. (2010). Correlates of job-related burnout in nurse managers working in hospitals (Doctoral dissertation, Rutgers University-Graduate SchoolNewark). 
Chiou, S. T., Chiang, J. H., Huang, N., Wu, C. H., \& Chien, L. Y. (2013). Health issues among nurses in Taiwanese hospitals: National survey. International journal of nursing studies, 50(10), 1377-1384.

Cole, M. S., Bernerth, J. B., Walter, F., \& Holt, D. T. (2010). Organizational justice and individuals' withdrawal: Unlocking the influence of emotional exhaustion. Journal of Management Studies, 47(3), 367-390.

Colquitt, J. A. (2001). On the dimensionality of organizational justice: a construct validation of a measure. Journal of applied psychology, 86(3), 386.

De Cremer, D., Van Knippenberg, B., Van Knippenberg, D., Mullenders, D., \& Stinghhamber, F. (2005). Rewarding leadership and fair procedures as determinants of self-esteem. Journal of Applied Psychology, 90(1), 3.

de França FM, Ferrari R, Ferrari DC, Alves ED. Burnout and labour aspects in the nursing teams at two medium-sized hospitals. Rev Lat Am Enfermagem. 2012;20(5):961-70, http:/dx.doi.org/10.1590/S0104-11692012000500019.

Delpasand, M., Raeissi, P., Begdeli, F., \& Shahabi, M. (2011). The impact of job rotation on nurses burnout in Ayatollah Kashani hospital, Tehran: A case study.

Elçi, M., Karabay, M. E., \& Akyüz, B. (2015). Investigating the mediating effect of ethical climate on organizational justice and burnout: A study on financial sector. Procedia-Social and Behavioral Sciences, 207, 587-597

Elkonin, D., \& Van der Vyver, L. (2011). Positive and negative emotional responses to work-related trauma of intensive care nurses in private health care facilities. Health SA Gesondheid, 16(1).

Fatt, C. K., Khin, E. W. S., \& Heng, T. N. (2010). The impact of organizational justice on employee's job satisfaction: The Malaysian companies perspectives. American Journal of Economics and Business Administration, 2(1), 5663.

Fortin, M. (2008). Perspectives on organizational justice: concept clarification, social context integration, time and links with morality. International Journal of Management Reviews, 10(2), 93-126. 
Gholampour, M., \& Pourshafei, H. (2018). The role of organizational justice in job satisfaction with nursing burnout mediation. Journal of Health and Care, 20(1), 7-17.

Gingras, J., De Jonge, L. A., \& Purdy, N. (2010). Prevalence of dietitian burnout. Journal of Human Nutrition and Dietetics, 23(3), 238-243.

Golparvar, M., \& Arizi, H. R. (2008). The comparison of beliefs in fair world for self and others in terms of sex, marital status, education, job, housing.

Guan, S., Xiaerfuding, X., Ning, L., Lian, Y., Jiang, Y., Liu, J., \& Ng, T. B. (2017). Effect of job strain on job burnout, mental fatigue and chronic diseases among civil servants in the Xinjiang Uygur Autonomous Region of China. International journal of environmental research and public health, 14(8), 872.

Gür, E. (2014). Organizational justice perception and burnout situations of nurses working in public, private and university hospitals [thesis]. Ankara: Gazi University Graduate School of Health Sciences.

Hatam, N., Fardid, M., \& Kavosi, Z. (2013). Perceptions of organizational justice among nurses working in university hospitals of shiraz: a comparison between general and specialty settings. Nursing and midwifery studies, 2(4), 77.

Heponiemi, T., Elovainio, M., Kouvonen, A., Kuusio, H., Noro, A., FinneSoveri, H., \& Sinervo, T. (2011). The effects of ownership, staffing level and organizational justice on nurse commitment, involvement, and satisfaction: A questionnaire study. International journal of nursing studies, 48(12), 1551-1561.

Ismail, L. S., Al Faisal, W., Hussein, H., Wasfy, A., Al Shaali, M., \& El Sawaf, E. (2015). Job satisfaction, burnout and associated factors among nurses in health facilities, Dubai, United Arab Emirates, 2013. American Journal of Psychology and Cognitive Science, 1(3), 89-96.

Jafari, P., \& Bidarian, S. (2012). The relationship between organizational justice and organizational citizenship behavior. Procedia-Social and Behavioral Sciences, 47, 1815-1820. 
Juan, D. V., Omar, A., \& Salessi, S. (2018). From organizational justice perceptions to turnover intentions: The mediating effects of burnout and job satisfaction. Europe's Journal of Psychology, 14(3), 554-570. doi:http://dx.doi.org/10.5964/ejop.v14i3.1490.

Karkar, A., Dammang, M. L., \& Bouhaha, B. M. (2015). Stress and burnout among hemodialysis nurses: A single-center, prospective survey study. Saudi Journal of Kidney Diseases and Transplantation, 26(1), 12.

Lahana, E., Papadopoulou, K., Roumeliotou, O., Tsounis, A., Sarafis, P., \& Niakas, D. (2017). Burnout among nurses working in social welfare centers for the disabled. BMC nursing, 16(1), 15.

Lambert, E. G., Hogan, N. L., Jiang, S., Elechi, O. O., Benjamin, B., Morris, A., \& Dupuy, P. (2010). The relationship among distributive and procedural justice and correctional life satisfaction, burnout, and turnover intent: An exploratory study. Journal of Criminal justice, 38(1), 7-16.

Lambert, E. G., Hogan, N. L., Barton-Bellessa, S. M., \& Jiang, S. (2012). Examining the relationship between supervisor and management trust and job burnout among correctional staff. Criminal Justice and Behavior, 39(7), 938-957.

Lambert, E. G., Hogan, N. L., \& Cheeseman, K. (2013). Research note-strainbased work-family conflict and its relationship with perceptions of distributive and procedural justice among correctional staff. Journal of Police and Criminal Psychology, 28(1), 35-47.

Laschinger, H. K. S., Wong, C. A., \& Grau, A. L. (2012). The influence of authentic leadership on newly graduated nurses' experiences of workplace bullying, burnout and retention outcomes: A cross-sectional study. International journal of nursing studies, 49(10), 1266-1276.

Leka, S., Jain, A., \& World Health Organization. (2010). Health impact of psychosocial hazards at work: an overview.

LIAO, B., XU, J. Y., \& TANG, S. T. (2012). Research on the Relationship between Organizational Justice, Colleague Affection and Sense of Accomplishment [J]. Soft Science, 4. 
Lind, E. A., \& Tyler, T. R. (1988). The social psychology of procedural justice. Springer Science \& Business Media.

Li, Y. (2014). Building affective commitment to organization among Chinese university teachers: the roles of organizational justice and job burnout. Educational Assessment, Evaluation and Accountability, 26(2), 135-152.

Lotfi, M. H., \& Pour, M. S. (2013). The relationship between organizational justice and job satisfaction among the employees of Tehran Payame Noor University. Procedia-Social and Behavioral Sciences, 93, 2073-2079.

Lu, H., Barriball, K. L., Zhang, X., \& While, A. E. (2012). Job satisfaction among hospital nurses revisited: a systematic review. International journal of nursing studies, 49(8), 1017-1038.

Maruyama, A., Suzuki, E., \& Takayama, Y. (2016). Factors affecting burnout in female nurses who have preschool-age children. Japan Journal of Nursing Science, 13(1), 123-134.

Maslach, C., Jackson, S.E., \& Leiter, M.P. (1996). Maslach Burnout Inventory Manual (3rd ed.). Palo Alto, CA: Con- sulting Psychologists Press.

Maruyama, A., Suzuki, E. and Takayama, Y. (2015). Factors affecting burnout in female nurses who have preschool-age children. Japan Journal of Nursing Science in press.

Maslach, C., \& Leiter, M. P. (2016). Understanding the burnout experience: recent research and its implications for psychiatry. World psychiatry, 15(2), 103-111.

McDermott, A. M., Keating, M. A., Chênevert, D., Jourdain, G., Cole, N., \& Banville, B. (2013). The role of organisational justice, burnout and commitment in the understanding of absenteeism in the Canadian healthcare sector. Journal of health organization and management. 27:350-67.

Mohamed, H., Higazee, M. Z. A., \& Goda, S. (2018). Organizational justice and workplace bullying: the experience of nurses. American Journal of Nursing, 6(4), 208-213. 
Mohamed, S. A. (2014). The relationship between organizational justice and quality performance among healthcare workers: A pilot study. The Scientific World Journal, 2014.

Moliner, C., Martínez-Tur, V., Peiró, J. M., Ramos, J., \& Cropanzano, R. (2005). Relationships between organizational justice and burnout at the work-unit level. International Journal of Stress Management, 12(2), 99.

Neami, A., \& Shokrkon, H. (2004). The relationship of organizational justice and organizational civic behavior of employees in Ahvaz industrial organizations. Journal of Psychology, (1-2).

Özer, Ö., Uğurluoğlu, Ö., \& Saygili, M. (2017). Effect of organizational justice on work engagement in healthcare sector of Turkey. Journal of Health Management, 19(1), 73-83.

Özsoy, Z., \& Ekici, D. (2017). Perception of Nurses Regarding Organizational Justice and Ethical Behavior; Organizational Culture in Hospitals. Hospital practices and research, 2(2), 41-46.

Pekurinen, V. M., Välimäki, M., Virtanen, M., Salo, P., Kivimäki, M., \& Vahtera, J. (2017). Organizational justice and collaboration among nurses as correlates of violent assaults by patients in psychiatric care. Psychiatric services, 68(5), 490-496

Rosales, R. A., Labrague, L. J., \& Rosales, G. L. (2013). Nurses' Job satisfaction and Burnout: Is there a connection?. International Journal of Advanced Nursing Studies, 2(1), 1.

Saeed, A., Syed, N., \& Faria Rabbi, M. F. (2015). The impact of organizational Justice on job burnout. Scholars Journal of Economics, Business and Management, 2(5), 519-522.

Safari, A., TamiziFar, M., \& Jannati, A. R. (2012). The effect of organizational justice and perceived organizational support on university staff job burnout (Case of University Staff of Isfahan). Australian Journal of Basic and Applied Sciences, 6(7), 131-136. 
Schaufeli, W., \& Salanova, M. A. R. I. S. A. (2014). Burnout, boredom and engagement at the workplace.

Seyrek, H., \& Ekici, D. (2017). Nurses' perception of organisational justice and its effect on bullying behaviour in the hospitals of Turkey. Hospital Practices and Research, 2(3), 72-78.

Shkoler, O., \& Tziner, A. (2017). The mediating and moderating role of burnout and emotional intelligence in the relationship between organizational justice and work misbehavior. Revista de Psicologia del Trabajo y de las Organizaciones, 33(2), 157-164.

Top, M., \& Tekingunduz, S. (2018). The Effect of Organizational Justice and Trust on Job Stress in Hospital Organizations. Journal of Nursing Scholarship, 50(5), 558-566.

Williamson, K., \& Williams, K. J. (2011). Organisational justice, trust and perceptions of fairness in the implementation of agenda for change. Radiography, 17(1), 61-66.

Yaghoubi, M., Afshar, M., \& Javadi, M. (2012). A study of relationship between the organizational justice and organizational citizenship behavior among nurses in selected hospitals of Isfahan University of Medical Sciences. Iranian journal of nursing and midwifery research, 17(6), 456.

Yang, J. H., \& Jung, H. Y. (2009). Relationship between violence response, coping, and burnout among emergency department nurses. Journal of Korean Academy of Fundamentals of Nursing, 16(1), 103.

Zhang, A. Q., Li, Z. Y., \& Wu, M. Z. (2012). The mediating effect of psychology capital between organizational justice and job burnout among rural primary and secondary school teachers. Chinese Mental Health Journal, 26(8), 635636. doi:10.3969/j.issn.1000-6729.2012.08.015 
ادرالك العدالة المؤسسية والاحتراق الوظيفي لاى الممرضين في مستثفيات

بورسعيد المختارة

شيرين صلاح الدسوقي- صفاء عبدالمنعم زهران- تقوى رشوان محمد عبد الهادى

أخصائية تمريض، بمستشفى الصدر بالمنصورة، محافظه الدقهلية ـ أستاذ مساعد إدارة التمريض ، كلية

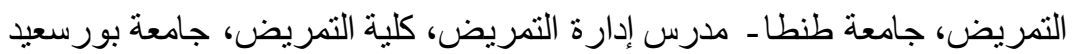

\section{الخلاصة}

تشير العدالة المؤسسية إلى رؤية الممرضون للإجراءات في مكان العمل و انخفاض مستويات العدالة في المنظمات يرجع لارتفاع مستويات الإرهاق الوظيفي بين المرضات. الهدف من الدراسة ايجاد العلاقة بين إدراك العدالة

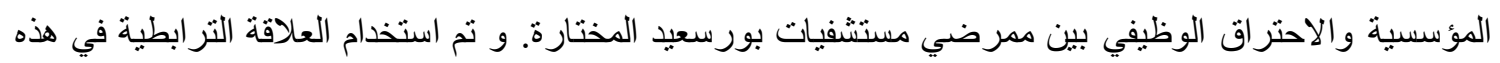
الدراسة في جميع أقسام المرضى الداخليين بمستشفيات بورسعيد المختارة على 206 ممرض. وقد وقد نم جمع البيانات باستخدام ورقتين الاستبيان الاول: مقياس العدالة المؤسسية والاستبيان الثاني مقياس الاحتراق الوظيفي. النتائج:

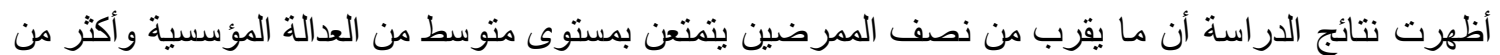
تلث الممرضين لديهم مستويات متوسطة من الاحتراق الوظيفي ، كان لدى أقل من ثلاثة أرباع الممرضين مستويات منخفضة من تبدد الشخصية. كما نوجد علاقة ارتباطية سالبة ذات دلالة إحصائية بين الدرجة الكلية للعدالة المؤسسية وأبعادها مع الاحتراق الوظيفي. الخلاصنة: مستوى منوسط من العدالة المؤسسية بين الممرضين ، و العدالة التفاعلية سجلت أعلى نسبة من وجهة نظر الممرضين. بينما، مستوى معتدل من الاحتراق الوظيفي. وتوجد علاقة ارتباط معنوية سلبية بين العدالة المؤسسية والاحتراق الوظيفي. ومع ذلك، توجد ارتباطات سلبية ذات دلالة إحصائية بين العدالة المؤسسية وأبعاد الاحتراق الوظيفي وتبدد الثخصية والاحتراق الوظيفي .التوصيات. توصي

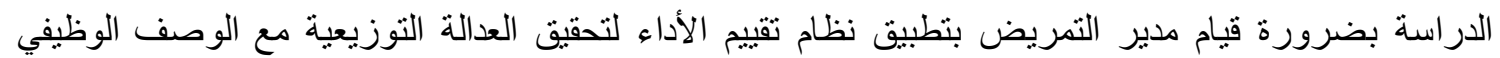

